\title{
베트남 국별지원전략(CAS) 및 지원사업 종합평가 : CAS를 중심으로
}

한국국제협력단 사업평가실1)

\section{목차}

I. 평가개요

II. 베트남의 개발환경

III. 대 베트남 지원전략(CAS) 평가

IV. 평가의 주요발견

V. 교훈 및 정책제언

\section{I. 평가 개요}

\section{1. 평가 목적}

베트남은 KOICA의 가장 중요한 중점 협력대상국 중의 하나로 1991 2008년간 약 8,938만 불 규 모의 지원이 이뤄졌으며 2010년 우리의 $\mathrm{OECD} / \mathrm{DAC}$ 가입과 $\mathrm{ODA}$ 확대 방침 등으로 베트남에 대한 지원규모는 점차 확대될 것으로 예상된다. 더불어 2005년 3월 “원조효과에 관한 파리선언" 국제사 회에서 $\mathrm{ODA}$ 효과제고에 관한 관심이 고조되고 있는바 베트남 국별지원전략(Country Assistance Strategy : CAS)평가를 통해 교훈을 얻고 피드백을 통해 원조정책의 보다 나은 발전과 체계적이고 전략적인 원조실시를 도모하고자 한다.

1) 한국국제협력단 사업평가실 박숙현 직원 요약·정리 


\section{2. 평가 대상}

- 대상: 2007년 11월말 수립된 대 베트남 국별지원전략(CAS)

- 최상위 목표: 빈곤해소 및 사회개발과 경제성장

- 4 대 지원목표
1) 사회개발/빈곤퇴치
2) 경제성장 촉진
3) 제도개선/능력강화
4) 환경·자원보존 개선

- 기본지원방향

1) 빈곤지역이자 우리와 역사적 관계가 있는 중부지역 중심으로 지원하되 소득수준이 비교적 낮은 북부지역에 대한 지원도 고려

2) 중앙정부 및 도시지역의 제도개선 및 능력강화, 환경, IT 사업에 우리의 개발경험전수 및 비 교우위분야 사업 추진

3) 원조사업 집행과정에서 베트남 정부의 개발계획과 합치되도록 베트남 측의 참여적 절차 활성 화 유도

4) MDGs 달성을 위한 빈곤퇴치 중심의 원조모델 도출

5) 주요 전략 및 프로그램 수준에서의 이해 제고 및 원조효과 배가를 위한 정책대화 활성화

6) 교훈확립을 통한 성공원조모델의 조기정착

- 지원분야
1) 보건의료
2) 교육
3) 행정제도
4) 산업에너지 분야
5) 환경 및 기타

\section{3. 평가 매트릭스}

$\mathrm{CAS}$ 는 통상 투입에 따른 결과를 평가하는 프로젝트의 경우와 달리 평가 5항목을 그대로 적용하기 어렵다. 따라서 CAS에 대한 평가는 국가전체에 대한 지원전략임을 고려해서 1) CAS 수립절차의 적절성, 2) $\mathrm{CAS}$ 구성체제의 적절성, 3) $\mathrm{CAS}$ 내용의 적절성, 4) $\mathrm{CAS}$ 활용의 적정성에 중점을 두어 평가했다. 또한 CAS 제도를 도입한 세계은행과 UN의 "UN Development Assistance Framework (UNDAP)" 및 일본, 영국 등 주요 양자 간 원조기구의 사례를 비교 검토하였다. 
〈표 1〉CAS 중점 평가항목

\begin{tabular}{|c|c|}
\hline 주요 평가 항목 & 세부 평가 항목 \\
\hline 수립절차의 적절성 & $\begin{array}{l}\text { 1. 수립체제의 적절성 } \\
\text { 2. 수립절차의 투명성 } \\
\text { 3. 국내외 관계자와의 충분한 의견수렴 및 동의절차의 적절성 }\end{array}$ \\
\hline 구성체제의 적절성 & $\begin{array}{l}\text { 1. 구성 항목의 적절성 } \\
\text { 2. 구성 항목 간 논리적인 인과관계의 적절성 }\end{array}$ \\
\hline 내용의 적절성 & $\begin{array}{l}\text { 1. 우리 정부의 상위 정책과 일치성 } \\
\text { 2. 베트남의 개발계획과의 일치성 } \\
\text { 3. 지원전략의 적절성 } \\
\text { 4. 타 원조기관의 지원내용과 조화 } \\
\text { 5. 국제원조규범과의 부합여부 }\end{array}$ \\
\hline 활용의 적절성 & $\begin{array}{l}\text { 1. 구체적 활용실태의 적절성 } \\
\text { 2. 국내외 관계자의 인지도 }\end{array}$ \\
\hline
\end{tabular}

\section{II. 베트남의 개발환경}

\section{ODA 지원과 경제사회발전}

베트남은 1980년대 중반까지 전쟁의 피해와 통제경제의 실패 등으로 절대빈곤 상태였으나 1986년 “도이 모이(Doi Moi : 개혁) 정책2)"을 도입하며 변화를 시도했다. 그러나 도이 모이 정책은 인프 라 부족, 비효율적인 공공행정제도, 세계경제와의 부조화, 인력의 역량부족 등을 이유로 효과를 보 지 못했다. 따라서 베트남에 대한 ODA는 이러한 장애요인들을 개선하는 방향으로 지원되어 왔다.

베트남에 대한 본격적인 원조는 1993년 11월 프랑스 파리에서 개최된 공여국 회의에서부터 시작되 었고 이후 지속적으로 규모가 성장하는 추세이다. $\mathrm{OECD}$ 및 세계은행 통계에 의하면 지불액 기준 으로 2005년 19억 500만 불, 2006년 18억 4600만 불, 2007년 24억 9700만 불이 지원되었다. 2006 2007년 평균 금액을 기준으로 베트남의 최대공여국은 일본이며 이어 IDA, 프랑스, 아시아 개발은행 및 독일 순이고 이들의 공여액이 전체 공여액의 $80 \%$ 를 차지하였다. 분야별로는 경제인 프라 분야가 약 $45 \%$, 기타 사회분야 $16 \%$, 생산 및 다분야가 각각 $10 \%$, 교육, 보건 및 인구 분야 가 각각 $7 \%$ 이다.

베트남은 사회주의의 내부지향적 중앙계획경제에서 시장경제체제로 전환하는 가운데 현재 가장 경 제성장이 빠른 나라 중의 하나로서 향후 성공적인 개발을 이룩할 수 있는 잠재력을 가지고 있다.

2) 도이 모이는 사회주의체제를 유지하면서 시장경제제도의 도입을 추진하는 정책이다. 
해외투자가 늘어나고 농지의 평등한 재분배, 농산물의 자유거래, 영농지원제도의 개선 등으로 농 산수출의 대폭 확대 및 농촌지역 빈곤이 현저히 감소하였다. 또한 민간부문이 성장원동력으로서 최근 민간 기업에 의한 투자가 전체의 절반 이상을 차지하고 있다. 빈곤비율은 1993 년 58\%에 달 하였으나 2006년 $16 \%$ 로 줄어들어 대부분의 MDGs를 달성할 것으로 보인다.

\section{2. 베트남 정부의 개발계획}

베트남 정부의 개발정책과 이의 집행은 체계적으로 수립된 일련의 전략과 계획에 근거하고 있으며 공공투자계획, 연도별 예산배분 등도 10 개년 전략과 5 개년 계획을 근간으로 수립되고 있다.

베트남 정부의 개발계획의 핵심은 제8차 사회경제개발5개년계획(SEDP)으로서 2006년 4월 제10차 공산당총회의 동의와 2006년 6월 국회의 승인을 받은 계획문서이다. $\mathrm{SEDP}$ 는 포괄적 빈곤삭감 및 성장전략(CPRGS)3), 베트남 개발목표(VDGs)를 포함하며 비전은 “2020년까지 공업국으로 발전”으 로 명시하고 있다. 또한 고도경제성장을 제1목표로 하는 6 대 목적 및 비전을 제시하면서 국민생활 의 안정, 경제구조의 전환 등에 중점을 두고 4대 전략을 통해 8대 과제를 해결하고 3개 개발 목 표를 달성하려는 계획을 하고 있다.

〈표 2〉베트남 정부의 개발계획

\begin{tabular}{|c|l|}
\hline 수립 연도 & \multicolumn{1}{|c|}{ 전략 및 계획명 } \\
\hline 2001년 수립 & $\begin{array}{l}\text { 제7차 사회경제개발5개년계회(2001 2005) } \\
\text { (7th Social and Economic Development Plan : SEDP) }\end{array}$ \\
\hline 2001년 수립 & $\begin{array}{l}\text { 2001 2010 사회경제개발전략 } \\
\text { (Social and Economic Devleopment Strategy : SEDS) }\end{array}$ \\
\hline 2002년 수립 & $\begin{array}{l}\text { 포괄적 빈곤삭감 및 성장전략 } \\
\text { (Comprehensive Poverty Reduction and Growth Strategy : CPRGS) }\end{array}$ \\
\hline 2006년 개정 수립 & $\begin{array}{l}\text { 제8차 사회경제개발5개년계회(2006 2010) } \\
\text { (8th Social and Economic Development Plan : SEDP) }\end{array}$ \\
\hline
\end{tabular}

3) 원래 CPRGS는 원조공여자의 요구에 따라 작성한 문서에 불과하고 국회의 승인을 받은 국가개발계획 기본문서는 SEDP이다. 그러나 원조공여자들이 CPRGS를 기본문서로 혼동하는 경우가 발생하자 2005년 원조자문그룹회의(Consultative Group Meeting, CGM)에서 원조공여국들이 제 8차 SEDP를 빈곤 감소전략으로 간주하여 자신들의 원조전략을 일치시 키기로 동의하였다. 세계은행도 2006년 12월 이사회에서 SEDP를 PRSP로 인정하였다. 
〈표 3〉베트남의 개발계획의 체계도

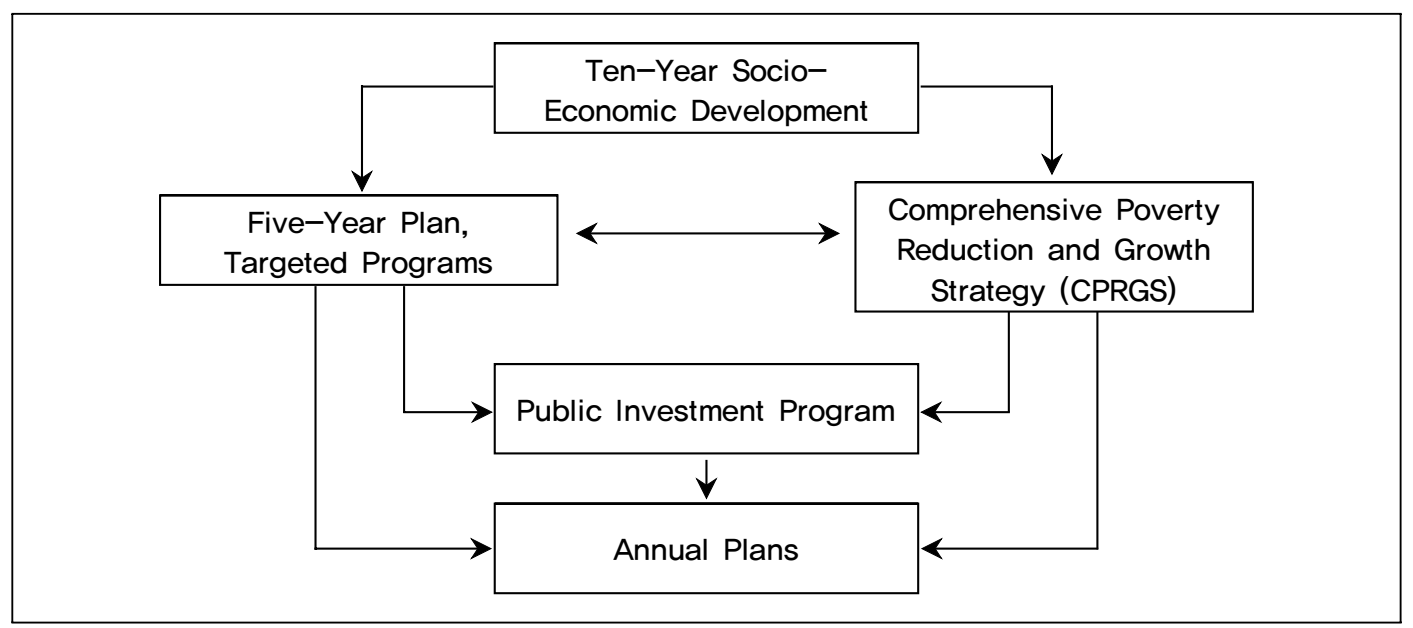

\section{III. 대 베트남 지원전략(CAS) 평가}

\section{1. 수립절차의 적절성}

1) 수립체제의 적절성

(1) 수립체제 및 본부와 현지의 역할분담

$\mathrm{CAS}$ 의 기본적인 수립체제는 다른 원조기관의 경우와 유사하며 특히 현장에서 주도적인 역할을 맡 아 추진한 점을 긍정적으로 평가한다. 또한 본부와 현지의 역할분담도 적절하게 이루어진 것으로 평가한다.

〈표 3-1〉 본부 및 현지와의 역할분담

\begin{tabular}{|l|l|}
\hline \multicolumn{1}{|c|}{ 본부 } & 베트남 \\
\hline - 외교통상부 & - 주베트남 대사관 \\
- CAS 수립지침 작성 및 시달 & - KOICA 작성 본부 보고용 초안검토 및 \\
- 외교통상부 내 의견 수렴 & 최종 보고안 작성 \\
- 관계부처 의견 수렴 & - 최종 보고안 본부 보고 \\
- 국제개발협력위원회 및 실무위원회 심의 안건 상정 & \\
\hline - KOICA & KOICA 사무소 \\
- 주베트남 대사관 보고안에 대한 검토 및 본부용 & - 본부 보고용 초안 작성 및 대사관 보고 \\
초안 작성 & \\
- 외교통상부에 초안 보고 & \\
\hline
\end{tabular}


〈표 3-2〉CAS 수립체제

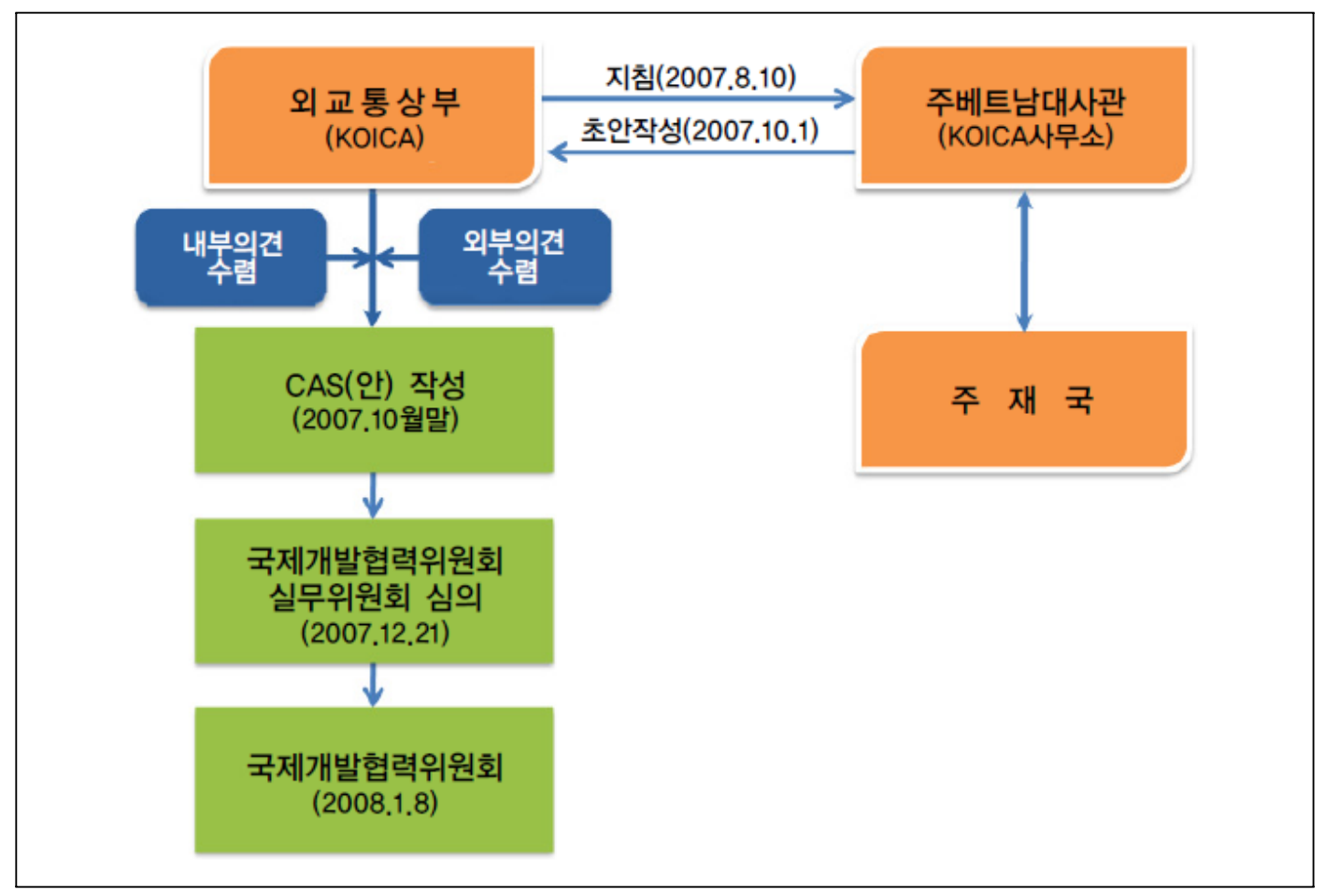

(2) 조직 및 인원

$\mathrm{KOICA} \mathrm{CAS}$ 수립은 별도의 전담반을 구성하지 않고 직제 상 업무분장에 따른 담당부서 및 담당 자에 의해 업무가 추진되었다. 그러나 $\mathrm{ADB}$, 세계은행, 영국, 일본 등 선진원조기관의 경우 대부 분 전담반을 구성하여 $\mathrm{CAS}$ 를 작성하고 있다.

$\mathrm{ADB}$ 의 경우, 지역담당, 분야별 담당, 기타 관계자 등으로 구성되는 국별 팀(Country Team)이 $\mathrm{CAS}$ 작성을 담당하고 지역담당 부총재가 관련 업무를 지도감독하며 본부의 지역관리팀이 품질보 증체제(quality assurance systems)를 수립한다. 세계은행의 경우에도 국별 팀을 구성하여 유사 한 절차에 의하여 업무를 추진한다. 영국 $\mathrm{DFID}$ 의 경우에도 역시 국별 팀을 구성하여 특히 $\mathrm{DFID}$ 내 국제과, 범세계적 개발효과 담당과, 정책 및 연구조사과, 지역과, 평가부, 기획 및 실행그룹 등 과 협의를 의무화하고 있다. 일본의 경우에도 본부 및 현지에 각각 전담반(task force)을 구성하 여 추진하고 있다.

이와 같이 $\mathrm{CAS}$ 수립이 다양한 연구조사 및 분석, 의견수렴을 필요로 하는 과정이므로 여타 원조 기관과 같이 전담조직을 구성하고 자문기구도 적극 활용할 필요가 있다. 
(3) 작성 주기

$\mathrm{KOICA}$ CAS는 3년 단위로 재검토하고 조정하도록 하고 있으나 베트남에 대한 $\mathrm{CAS}$ 를 이미 수립 해온 원조기관들은 베트남 정부의 5 개년개발계획을 감안하여 대부분 5 년을 단위로 $\mathrm{CAS}$ 를 수립하 고 있다. 따라서 베트남 정부의 개발계획에 대한 일치성, 다른 원조기관과의 조화성, 우리의 원조 규모 대비 행정비용의 과다한 측면을 고려하여 $\mathrm{CAS}$ 의 작성주기를 5 년 단위로 하는 것이 바람직할 것이다.

\section{(4) 수립절차}

KOICA는 2005년 9월 외부연구용역과제인 “베트남을 위한 중장기 원조사업계획”을 발간하였는데 이는 2007년 외교통상부가 CAS 수립 시 기초가 되었다. CAS 수립을 위한 정부차원의 논의는 2007년 7월 20일 개최된 제2차 국제개발협력위원회에서 "공적개발원조(ODA) 중기전략(2008 2010)" 을 채택한 이후부터 본격화되었으며 외교통상부는 2007년 8월 7일 “국별지원전략 작성지침”을 작 성하여 동년 8월 10일 주 베트남 대사관을 포함 해당 공관 및 $\mathrm{KOICA}$ 에 하달하였다. 이후 동년 10 월 1일 주 베트남 대사관 $\mathrm{CAS}$ (안)을 본부에 보고하였으며 이를 토대로 외교통상부는 11월말 대 베트남 CAS를 포함한 “대외무상원조 국별전략”을 발간하였다.

〈표 4〉외교부 지침 주요 내용

\begin{tabular}{|c|c|}
\hline 구분 & 내용 \\
\hline 대상기간 & - 2008 2010, 향후 3년 주기로 작성하되 필요시 매년 수정 가능 \\
\hline 주요내용 & $\begin{array}{l}\text { - 수원국의 개발환경 : 수원국의 개발상황, 개발정책 및 개발과제 등 } \\
\text { - 우리의 지원전략 : 주점지원분야, 분야별 개발전략 및 목표 등 } \\
\text { - 중기 재원배분계획 }\end{array}$ \\
\hline 환류과정 & $\begin{array}{l}\text { - ODA 중기전략 } \rightarrow \text { 국별지원전략 } \rightarrow \text { 연도별 사업계획 } \rightarrow \text { 사업진행 } \rightarrow \text { 모니터링 및 평가 } \rightarrow \\
\text { ODA 중기전략 수립 반영 }\end{array}$ \\
\hline 추진일정 & $\begin{array}{l}\text { - 2007.9.21 : 공관별 초안 작성 } \\
\text { - 2007.10.10 : 외교통상부안 작성(개발ㅎㅕㅕ력정책관실 주관, 지역국, KOICA 등 의견 수렴) } \\
\text { - 2007.10.31 : 무상원조 “국별지원전력" 확정 }\end{array}$ \\
\hline & - 베트남 CAS(안) 샘플로 송부 \\
\hline
\end{tabular}

(5) 소요기간

CAS는 2007년 7월 20일 개최된 제2차 국제개발협력위원회에서 “공적개발원조(ODA) 중기전략"을 채택한 이래 2007년 11월 30일 외교부 CAS가 수립되기까지 131일(약 4개월 10일)이 소요되었다.

선진원조기관의 경우 통상 현지사무소에 의한 자체평가와 본부의 평가전담부서(외부 위탁)에 의한 평가를 실시하는데 세계은행의 경우 협의 절차에만 2 년이 소요되었으며 일본의 가이드라인은 시안 
이 마련된 이후부터 6개월 내지 1년을 상정하고 있다.

반면 $\mathrm{CAS}$ 수립에 약 130 일이 소요되었으나 전담조직이 구성되지 않은 점을 감안할 때 투입된 실 질적인 소요일수는 이보다 적을 것으로 예상한다. 따라서 $\mathrm{CAS}$ 초안의 작성에 앞서 업무단계별 적 정 소요기간을 명확히 할 필요가 있다.

\section{2) 수립절차의 투명성}

$\mathrm{CAS}$ 수립관련 대부분의 원조기관은 정보를 적극적으로 공개4)하고 있으나 우리나라의 CAS는 적 극적인 노력이 부족했다. 향후 $\mathrm{CAS}$ 를 수립할 경우에는 관련된 조직내부와 홈페이지 게시 등을 통 하여 일반인에게도 적극적으로 정보공개 노력을 강화할 필요가 있다.

\section{3) 의견수렴 및 동의절차의 적절성}

$\mathrm{CAS}$ 수립과정에 있어 내부의견수렴을 위한 구체적인 절차가 명확히 드러나지 않았는데 이는 시간 적 여유가 충분하지 않았기 때문일 것으로 추측한다. 그러나 세계은행의 CSP(2007 2011)는 협의 과정에 관한 별도의 부속자료(Annex 4)를 포함하고 있으며 CSP수립을 위해 베트남 내 중앙정부, 지방정부, 민간부문, 시민사회 등 이해관계자들을 대상으로 조사를 실시하고 2 년간의 협의과정을 거쳤다.

\section{2. 구성체제의 적절성}

\section{1) 타 원조기관 CAS와의 비교}

\section{(1) CAS의 성격}

세계은행과 $\mathrm{ADB}$ 의 경우)는 $\mathrm{CAS}$ 가 전략문서 및 집행문서의 기능을 가지고 분야별, 과제별 상세 분석을 기초로 실행 가능한 구체적인 전략 및 행동계획을 제시하고 있다. 반면 양자 간 원조기관6) 의 경우 대부분 CAS가 강제적인 집행문서의 성격보다는 정책방향을 제시하는 유도적인(indicative rather than imperative) 성격의 문서라 할 수 있다.

4) $\mathrm{ADB}$ (CAS관련 문서 공개방침), 세계은행(세계은행 정보공개 정책에 따라 정보공개 및 정보공개 핸드북 활용), $\mathrm{DFID}$ (가 이드라인에 따라 초안을 웹사이트에 최소 12주 게시), 일본(가이드라인에 따라 1차안을 홈페이지에 게시하고 의견을 수 렴한 뒤 최종안 작성)

5) 세계은행의 경우 CSP 성과 매트릭스, VDGs, Hanoi Core Statement 등의 지표관리를 이행하며 ADB는 모니터링 및 평가 프레임워크, MDG 지표, 공여국 조정 매트릭스 및 각종 지표관리를 이행하고 있다.

6) 대부분 브로셔 형태로 홍보목적 즉 공표효과 혹은 교육효과의 성격도 가지고 있다. 


\section{(2) CAS 구성 논리체계}

일본, CIDA, AusAID의 경우는 납세자에 대한 홍보 및 개발교육을 의도하여 국익차원 ODA 중요 성을 언급하고 있으며 $\mathrm{ADB}, \mathrm{DFID}, \mathrm{SIDA}$ 등은 $\mathrm{ODA}$ 의 역할을 언급하고 있다. 특히 AusAID는 $\mathrm{PDM}$ 방식을 원용한 목표체계도(Outcome $\rightarrow$ Objective $\rightarrow \mathrm{Goal}$ 를 활용하는 특징을 띠고 있다. 원조기관별로 목차 및 순서에 차이가 있지만 일반적인 체계는 다음과 같다.

〈표 5〉CAS 구성체계

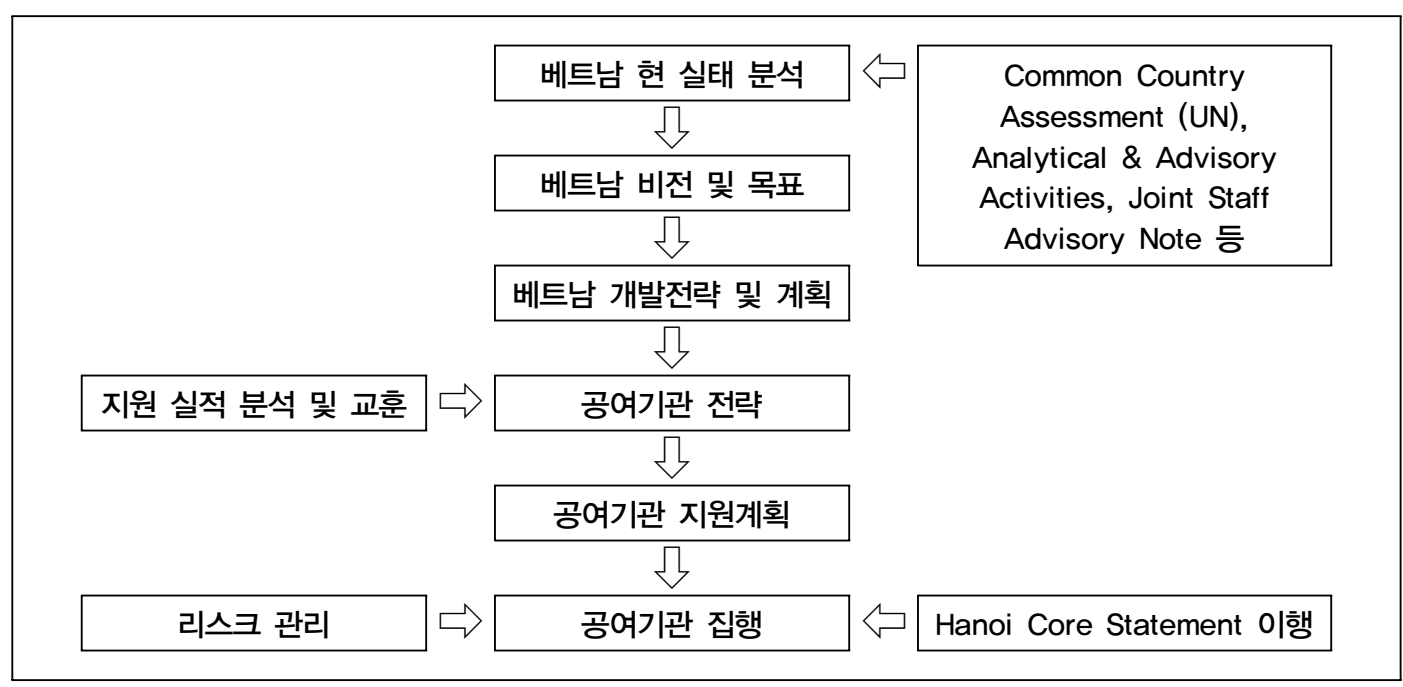

2) 구성 항목

$\mathrm{KOICA} \mathrm{CAS}$ 와 여타 원조기관의 CAS체제는 현 실태분석, 베트남의 비전 및 목표, 베트남의 개발 전략 및 계획, 공여국의 지원 실적 및 교훈, 공여기관 지원전략 항목은 공통적으로 포함하고 있으 나 $\mathrm{KOICA} \mathrm{CAS}$ 에는 리스크관리, 원조효과제고방안, 기타(공여국의 $\mathrm{ODA}$ 정책 및 $\mathrm{ODA}$ 의 역할) 항 목이 포함되지 않았다.

3) 논리적 구조

\section{(1) 구성 체제}

CAS의 핵심부분인 IV.지원전략 부분은 (1)원조목적, (2)지원목표, (3)기본지원방향, (4)지원분야로 구 성되고 있다. 즉, 기본지원방향에 따른 분야별 지원(투입)이 이뤄지면 그 성과로서 지원목표가 달 성되고 지원목표가 달성되면 원조목적이 달성된다는 논리적인 구조를 가지고 있다. 
(2) 지원목표 및 분야

지원목표는 베트남의 $\mathrm{SEDP}$ 는 물론 세계은행, $\mathrm{ADB}$, 호주, 일본 등 거의 대부분의 경우 목표달성 을 위한 “전략”과 유사한 내용이다.7) 그러나 지원전략(지원목표)과 분야와 관계에 있어 베트남 $\mathrm{SEDP}$ 및 다른 원조기관의 경우 성과위주의 계획이라는 관점에서 각 전략목적이나 목표달성을 위 한 투입의 수단으로서 분야를 다루고 있기 때문에 각 원조기관의 $\mathrm{CAS}$ 는 베트남의 $\mathrm{SEDP}$ 의 분야가 아니라 지원목적 및 목표에 일치시키고 있다. 반면 KOICA CAS의 경우 지원전략(지원목표) 및 분 야가 별도의 항목에서 다뤄지고 있어 베트남 $\mathrm{SEDP}$ 와 일치성을 파악하기 어려운 문제점이 있다.

〈표 6-1〉 제8차 SEDP의 4대 전략

\begin{tabular}{|l|l|l|l|}
\cline { 2 - 3 } \multicolumn{1}{c|}{} & \multicolumn{3}{c|}{ 4대 전략 및 목적 } \\
\hline I. 사업환경개선 & II. 사회부문강화 & III. 천연자원 및 환경 & IV. 가버넌스 강화 \\
- 기업경쟁력 강화 & - 기초서비스 확대 & 관리 강화 & - 제도정비 \\
- 재정시스템 효율화 & - 농업농촌개발 & - 삼림, 토지, 수자원, & - 공공자원 관리 \\
- 인프라서비스 확충 & - 취약계층 지원강화 & 생물다양성 관리강화 & 효율성 제고 \\
& & - 도시환경악화 감소 & - 부패방지 \\
\hline
\end{tabular}

〈표 6-2〉 세계은행 전략

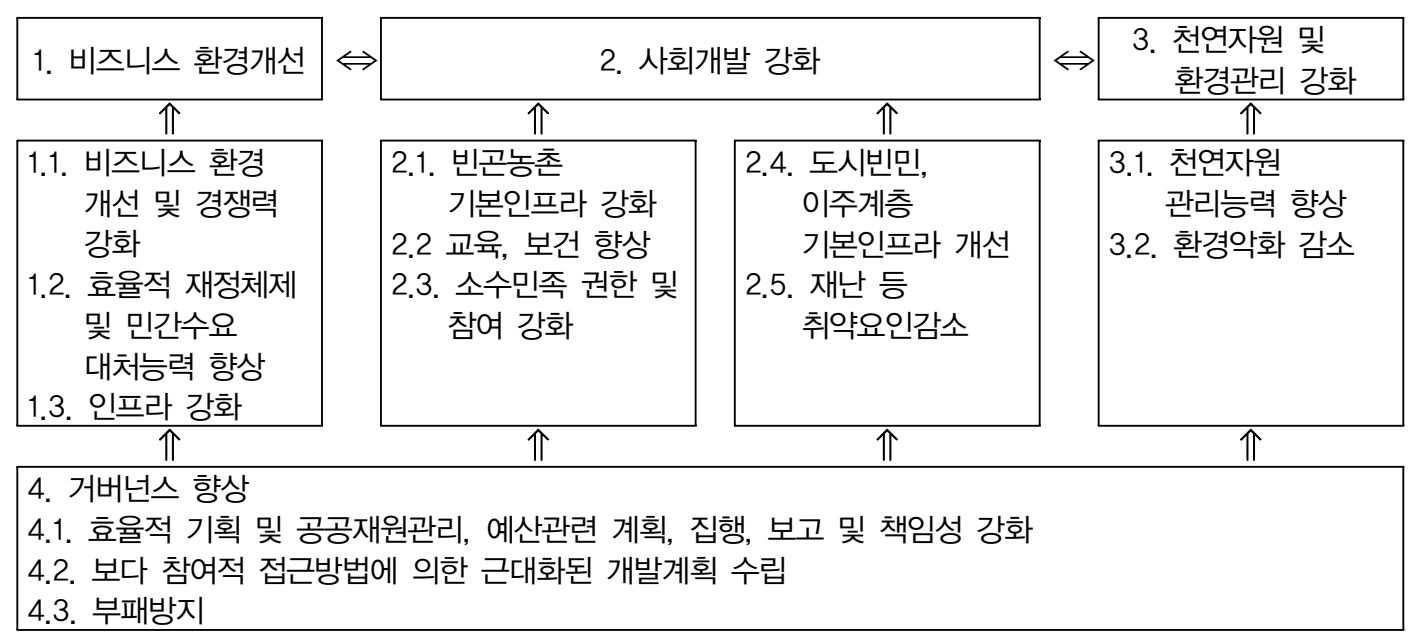

7) SEDP에서 Pillar I, II, III,IV로, 원조기관별로 Overall Objectives, Strategic Focus 등의 표현을 쓰고 있으나 내용상 "전략"으로 보는 것이 무난할 것으로 판단된다. 


\section{3. 내용의 적절성}

\section{1) 우리정부 상위정책과의 일치성}

$\mathrm{ODA}$ 정책과 관련된 정부차원의 사실상 유일한 최근 문서는 “ODA 중기전략(2008 2010)"이다. 이 중 CAS에 해당하는 부분은 "1. 중기 ODA 추진방향" 중 "나"항의 세 번째 "전략적 대외원조사 업 추진”으로 (1) 선택과 집중의 원칙, (2) 협력대상국별 개발전략에 기초한 목표 중심적, 성과지 향적인 종합 개발형 원조 제공, (3) 무상과 유상, 양자와 다자 등 다양한 형태의 대외원조 사업간 연계·조화를 통한 원조 효율성 및 효과성 제고 등 3 가지 내용을 포함하고 있다.

“선택과 집중”의 원칙과 관련 KOICA CAS는 지원목표와 분야를 정한 것으로 판단된다. 그러나 지원 분야의 경우, 베트남의 $\mathrm{ODA}$ 배분(안), 우리의 비교우위 및 지원능력, 세계적 개발원조 동향 등을 감안하여 선정하였다고 언급하고 있지만 기준에 대한 명확한 설명이 필요하다. 예를 들어 베 트남의 제8차 $\mathrm{SEDP}$ 에서 강조하는 “지식기반경제의 개발”과 관련된 “정보통신개발”이 강조되고 있으나 지원 분야에서 빠져있다. 또한 베트남의 제8차 SEDP는 친빈곤계층(Pro-poor focus) 성격 이 강한데 농촌개발 분야 역시 제외된 이유가 불분명하다. 따라서 중점분야의 선정근거를 좀 더 명확히 밝힐 필요가 있는데 이는 분야를 목적 또는 성과의 달성을 위한 수단으로 다룰 경우 해소 될 수 있을 것이다.

또한 수원국의 개발전략과 일치와 분야별 접근방법(Sector-wide Approaches : SWAPs), 프로그 램형 접근방법(Program-based Approaches : PBAs)등의 접근방법을 도입하고 성과위주의 모니 터링 및 평가를 위한 매트릭스 또는 프레임워크 제도가 필요하다.

마지막으로 “ODA 중기전략” 추진방향 중 유·무상 및 다양한 원조형태의 조화를 통한 원조 효과 성 제고에 대해서 KOICA CAS는 무상과 유상, 양자와 다자 등 원조사업간 연계 및 조화 도모에 관해서 다루지 않고 있다.

따라서 $\mathrm{KOICA} \mathrm{CAS}$ 에서 가장 중요하게 다뤄야 할 점은 성과위주의 목표, 관리 및 평가체제에 대 한 반영이다. 분야에 구애받을 필요 없이 KOICA CAS의 최상위 목표 중의 하나인 “빈곤해소"라 는 목적을 달성하는데 IT, 농촌개발, 교육, 보건 등 다양한 분야의 사업이 필요한 것이다. 성과위 주의 논리모형접근(Logical Framework Approach : LFA)을 적용하고 있는 선진원조기관의 CAS 와 같이 논리적인 인과관계를 명확히 한다면 이 부분을 보완할 수 있을 것이다. 
2) 베트남 개발계획과의 일치성

$\mathrm{KOICA}$ CAS의 (1) 사회개발 및 빈곤 퇴치는 $\mathrm{SEDP}$ (2) 사회부문 강화에, KOICA CAS의 (2) 경제 성장 촉진은 $\mathrm{SEDP}$ 의 (1) 사업 환경 개선에, $\mathrm{KOICA} \mathrm{CAS}$ 의 (4) 환경 및 자원보존 개선은 $\mathrm{SEDP}$ 의 (3) 천연자원 및 환경관리 강화에, KOICA CAS의 (3) 제도개선 및 능력강화는 $\mathrm{SEDP}$ 의 (4) 거버 넌스 강화와 일치한다고 볼 수 있다.

〈표 7〉제8차 SEDP 및 KOICA CAS 비교

\begin{tabular}{|c|c|c|}
\hline 구분 & 제8차 SEDP & KOICA CAS \\
\hline 장기비전 & - 2020년까지 공업국으로 발전 & SEDP의 내용을 전제로 함 \\
\hline 개발목표 & - 각 부문별 계량화된 목표 제시 & 상동 \\
\hline 6대 목적 & $\begin{array}{l}\text { (1) 지속적 성장 및 개발 가속화 } \\
\text { (2) 제반생활의 대폭 개선 } \\
\text { (3) 공업화, 근대화, 지식기반경제발전 } \\
\text { (4) 정치적, 사회적 안정 } \\
\text { (5) 국가안전보장 } \\
\text { (6) 국가위상 제고 등 }\end{array}$ & 상동 \\
\hline 4대 전략 & $\begin{array}{l}\text { (1) 사업환경 개선 } \\
\text { (2) 사화부문 강화 } \\
\text { (3) 천연자원 및 환경관리 강화 } \\
\text { (4) 거버넌스 강화 }\end{array}$ & 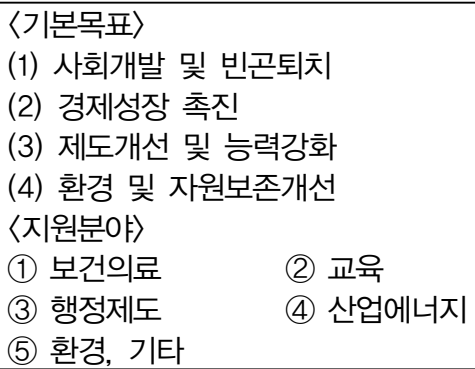 \\
\hline 8대 과제 & \begin{tabular}{ll} 
(1) 생산력, 경쟁력 강화 & \multicolumn{1}{c}{$(2)$ 시장경제화 } \\
(3) 국제경제통합 & (4) 과학기술개발 등 \\
(5) 국민생활 향상 & (6) 평등하고 풍요한 사회건설 \\
(7) 거버넌스 강화 & (8) 안전보장, 안정 등 \\
\end{tabular} & SEDP의 내용을 전제로 함 \\
\hline
\end{tabular}

3) 지원전략 내용의 적절성

(1) 원조목적

$\mathrm{KOICA} \mathrm{CAS}$ 에는 원조목적으로서 (1)빈곤해소, 사회개발 및 경제성장 (2)선택과 집중의 원칙 등 두 가지를 제시하고 있다. 그러나 “선택과 집중” 원칙은 원칙에 관한 사항이므로 원조 목적의 적합성 이 낮은 것으로 보여 조정이 필요하다.

(2) 기본 지원방향

기본 지원방향은 문제분석이 아닌 목적 달성을 위한 방법론 내지 방향성이므로 LFA에서 수단과 
목적의 인과관계 관점에서 검토할 필요가 있고 적용의 포괄성의 측면에서 검토할 필요가 있다.

우선 교훈 확립과 성공원조모델의 조기 정착과 관련하여 이는 원조효과의 제고라는 목적을 달성하 기 위한 하나의 과정에 불과하므로 방향으로 설정하는 것은 적절치 않다. 또한 교훈은 원조효과제 고를 위한 파리선언의 원조성과 관리 및 상호책임성의 모니터링 및 평가와 관련된 사항이므로 "원 조교훈 확립 ↔ 성공원조모델”의 관계를 “원조성과관리 및 상호책임성”의 관계로 바꿀 필요가 있 다고 판단된다.

원조모델의 도출과 $\mathrm{MDGs}(\mathrm{VDGs})$ 달성과의 관계에 대해서는 $\mathrm{MDGs}(\mathrm{VDGS})$ 달성이 $\mathrm{CAS}$ 기본목적 과 관련되는 사항이므로 기본 지원방향이 추진과정의 방법론 및 방향성이라는 관점에서 볼 때 적 절치 않은 것으로 보인다. 또한 빈곤퇴치중심의 원조모델이 VDGs의 달성에 기여하는 것은 사실이 나 이 항목만 VDGs와의 직접적인 관계를 언급하여 다른 항목과 형평성이나 논리성 면에서 무리 한 측면이 있다고 볼 수 있다.

기본방향의 “적용의 포괄성”이라는 측면에서는 “중부지역 중점지원 및 북부지역배려”와 “중앙정부 및 도시 지원방향” 부분이 지원방향으로서 적절치 않다고 판단된다. 전자는 최근 지역 도시내부의 빈곤격차, 취약계층 보호문제 등이 부각되고 있는 점을 고려할 때 지역적 기준만으로 기본방향을 설정하여 소외계층에 대한 배려가 약해지는 문제가 제기될 수 있다. 후자는 최근 지역사회의 역량 강화의 중요성, 농촌주민이 환경의 1 차적 이용자 및 훼손자라는 점에서 농촌지역의 환경문제, 지 역 간 IT격차 해소가 중요한 과제임을 감안할 때 이러한 내용도 다른 부분에서 관련된 사항을 다 루는 것이 바람직할 것이다.

\section{(3) CAS 내용간의 연계성}

CAS의 “평가 및 교훈” 부분은 Hanoi Core Statement의 핵심적인 사항과 일치하는 것으로 과거 지원을 통한 경험과 교훈이 뒷부분의 지원 전략에 반영되어야 하나 이에 대한 구체적인 실행방안 에 대해서는 구체적인 언급이 없다.

\section{4) 국제원조규범과의 부합성}

(1) 베트남 개발목표(Vietnam Development Goals : VDGs)

베트남정부는 MDGs를 기초로 11 개의 베트남 개발목표(세부목표 30 개)를 정하여 이의 달성을 위 하여 노력 중인 바 $\mathrm{CAS}$ 의 관련 내용이 대부분 $\mathrm{VDGs}$ 의 재용과 일치하고 있다. CAS에 직접적으로 
언급하지 않은 양성평등 및 여성권한강화는 연수과정 등을 통해 지원하고 있고 산모건강증진은 보 건의료분야의 지원을 통해, 취약계층감소, 소수민족 불평등 감소는 각종 지원을 통해 직간접적으 로 기여하고 있다고 볼 수 있다.

(2) Hanoi Core Statement (HCS)와의 조화성

$\mathrm{CAS}$ 의 지원전략 부분에서 $\mathrm{HCS}$ 와 관련되어 언급하고 있는 부분은 “원조 목적”에 제시된 아래 부 분에 불과하다.

대 베트남 무상원조의 최상위 목표는 베트남 정부의 빈곤해소 및 사회개발과 경제성장 지원임. (주인의 식과 일치성과 관련)

베트남의 개발전략과 우리의 무상원조 추진전략 및 베트남 정부와의 정책대화 등을 통해 도출된 우선 지원 요청분야 등을 반영, 선택과 집중의 원칙하에 반영. (주인의식과 일치성과 관련)

\section{CAS 활용의 적정성}

$\mathrm{CAS}$ 는 정책차원 및 실무차원에서 활용되고 있으나 대외보안취급문서로 분류되어 있고 영문판이 없으며 국별 단행본이 아닌 19 개 합본으로 되어 있어 대내외 홍보 및 정보전달에 한계가 있다. CAS의 핵심부분인 “대외무상원조 지원전략" 부분은 기본적인 방향성만 간략하게 언급하고 이행과 관련한 리스크관리, 모니터링 및 평가에 관한 사항이 포함되어 있지 않다.

\section{IV. 평가의 주요발견}

대 베트남 CAS수립은 최초의 “대 베트남 대외무상원조전략”이라는 점에서 큰 의의가 있으나 3 가 지 영역에서 한계점이 발견되었다.

첫째, $\mathrm{CAS}$ 구성절차 및 체제에서 약 4 개월간의 제한된 기간에 전담조직을 설치하지 않고 추진되 어 $\mathrm{CAS}$ 수립에 필요한 조사 및 평가단계가 생략될 수밖에 없었고 조직차원의 역량을 동원하는데 한계가 있었다. 
둘째, 내용면에 있어서 타 원조기관이 대부분 포함하고 있는 리스크 관리 및 원조효과성 제고를 위한 파리선언의 이행방안이 포함되어 있지 않으며 원조목적, 지원 목표, 기본지원방향 및 지원분 야간의 논리적 인과관계가 불분명하다.

마지막으로 $\mathrm{CAS}$ 활용 면에서 $\mathrm{CAS}$ 가 대외보안취급문서로 분류된 점이나 영문판의 부재, 합본 발 간된 점은 적극적인 활용에 제한사항으로 작용한다.

\section{V. 교훈 및 정책제언}

\section{1. 교훈}

베트남은 파리선언을 현지화한 $\mathrm{HCS}$ 를 발표하고 성과중심의 $\mathrm{SEDP}$ 를 수립하였으므로 $\mathrm{CAS}$ 도 전략 적으로 차별화할 뿐 아니라 현행 수단위주에서 성과위주로 원조방식을 전환해야 한다.

성과위주 원조의 핵심은 파트너십이다. CAS의 강점은 정부, 시민사회 및 개발파트너들과 함께 형 성해온 파트너십에서 나온다. 현재 베트남의 경우 정부 주도하에 다양한 파트너십 그룹이 활동하 고 있으므로 이들의 활동에 우리가 적극적으로 참여하고 우리의 비교우위가 있는 분야 및 과제에 서는 주도적인 역할을 담당하여 우리가 원하는 방향으로 원조를 유도할 필요가 있다. 또한 원조조 화 및 단순화를 위한 각종 공동연구조사활동, 공통된 프로그램 및 프로젝트의 방법론의 적용은 물 론 정부주도의 분야별 프로그램에 대해 선별적으로 참여하고 새로운 원조모델의 적용에 대응하여 현지의 $\mathrm{ODA}$ 주류그룹의 일원으로 활동하는 것이 중요하다.

성과위주의 원조와 파트너십을 강화하기 위해서는 우리의 비교우위를 반영하여 타원조기관의 중복 을 피하고 시너지 효과를 창출할 수 있도록 가장 성과와 파급효과가 큰 핵심과제에 선택적인 협력 사업을 지원할 수 있도록 해야 한다. 이를 위해서 현장중심의 업무체제로 전환할 필요가 있겠다.

\section{2. 정책제언}

첫째, CAS와 일치성을 강화하기 위해 다른 선진원조기관과 마찬가지로 개발전략 및 계획수립단계 부터 우리 측이 KOICA 원조프로그램의 일환으로 적극 참여하도록 한다. 이를 위해 현재 KOICA 에서 추진 중인 “한국의 개발경험공유 사업”을 전략적으로 적극 활용할 필요가 있다. 
둘째, 전략적인 지원전략을 마련해야 한다. 1998년 세계은행이 발행한 “원조평가”에 의하면 개도 국의 경제발전을 가로막는 장애요인은 정책 및 제도격차이고 원조의 양과 당해 국가의 개발과 개 혁은 반드시 비례관계가 아니며 물질적 지원보다는 개발과 개혁에 관련된 새로운 정보와 지식전수 가 훨씬 중요하다고 언급했다. KOICA는 원조재원이 부족하지만 개발경험이 풍부한 점에서 유리 한 위치에 있으므로 앞서 언급한 것과 같은 맥락에서 원조전략을 마련해야 할 것이다.

셋째, 국내외 이해관계자와 파트너십을 바탕으로 $\mathrm{CAS}$ 수립에 관한 명확한 지침 및 가이드라인을 마련한다. 지침 및 가이드라인은 다음 사항을 정하도록 한다.

CAS 수립 대상국, 수립체제(본부와 현지의 업무분담, 조직 및 인력), 수립주기(연간 및 중간평가 포함) 및 수립소요기간 CAS의 발행 형식과 분량

CAS 수립절차(정보공개, 국내외 업무협의 등 의견 수렵 절차 등) CAS 구성 항목 및 작성요령

MDGs 및 파리선언의 이행, 환경 및 성주류화 등과 관련한 사항

- 각종 지표 및 매트릭스 등 첨부해야할 자료 및 서류 등 